\title{
INCOME PACKAGING AND ECONOMIC DISCONNECTION: DO SOURCES OF SUPPORT DIFFER FROM OTHER LOW-INCOME WOMEN?
}

\author{
By
}

\author{
Andrea Helting \\ Rutgers University
}

\author{
Jinwoo Kwon \\ Rutgers University
}

Elizabeth Mahn

Rutgers University

\section{CES 13-61 December, 2013}

The research program of the Center for Economic Studies (CES) produces a wide range of economic analyses to improve the statistical programs of the U.S. Census Bureau. Many of these analyses take the form of CES research papers. The papers have not undergone the review accorded Census Bureau publications and no endorsement should be inferred. Any opinions and conclusions expressed herein are those of the author(s) and do not necessarily represent the views of the U.S. Census Bureau. All results have been reviewed to ensure that no confidential information is disclosed. Republication in whole or part must be cleared with the authors.

To obtain information about the series, see www.census.gov/ces or contact Fariha Kamal, Editor, Discussion Papers, U.S. Census Bureau, Center for Economic Studies 2K132B, 4600 Silver Hill Road, Washington, DC 20233, CES.Papers.List@census.gov. 
Income Packaging and Economic Disconnection: Do Sources of Support Differ from other LowIncome Women?

Andrea Hetling, Ph.D.

Bloustein School of Planning and Public Policy

Rutgers, The State University of New Jersey

33 Livingston Avenue

New Brunswick, NJ 08901

ahetling@rutgers.edu

(Corresponding author)

Jinwoo Kwon, MRP, Ph.D. Candidate

Bloustein School of Planning and Public Policy

Rutgers, The State University of New Jersey

Elizabeth Mahn, MPP

Bloustein School of Planning and Public Policy

Rutgers, The State University of New Jersey

Submitted: Journal of Sociology and Social Welfare

Date: July 29, 2013

This research utilized restricted-use microdata from the U.S. Census Bureau analyzed at the New York Census Research Data Center at Baruch College, a secure laboratory, operated in partnership with the U.S. Census Bureau's Center for Economic Studies. Any opinions and conclusions expressed herein are those of the authors and do not necessarily represent the views of the U.S. Census Bureau. All results have been reviewed to ensure that no confidential information is disclosed. The project was supported in part by grants from the Fahs-Beck Fund for Research and Experimentation in the New York Community Trust and Rutgers University Faculty Council. 
INCOME PACKAGING AND ECONOMIC DISCONNECTION

Income Packaging and Economic Disconnection: Do Sources of Support Differ from other LowIncome Women?

\begin{abstract}
Income packaging, or piecing together cash and non-cash resources from a variety of sources, is a common financial survival strategy among low-income women. This strategy is particularly important for economically disconnected women, who lack both employment income and public cash assistance receipt. Using data from the confidential Census Bureau versions of the Survey of Income and Program Participation, this study compares the use of public and private supports between disconnected and connected low-income women, controlling for differences in state welfare rules and county unemployment rates. Findings from bivariate comparisons and multilevel logistic regressions indicate that disconnected women utilize public non-cash supports at similar rates to connected women, but rely more heavily on private sources. Conclusions focus on the policy implications for outreach and program development.
\end{abstract}

Keywords

Economically disconnected women, income packaging, low-income families 


\section{INCOME PACKAGING AND ECONOMIC DISCONNECTION}

The proportion of low-income mothers who report no employment earnings or public cash assistance income has grown notably since the implementation of the welfare reform legislation of 1996 (Loprest \& Nichols, 2011). Studies show that significant numbers of Temporary Assistance for Needy Families (TANF) recipients leaving the program are not obtaining work, with estimates hovering around 40 percent (Acs \& Loprest, 2004; Loprest \& Zedlewski 2006). These women, often referred to as economically disconnected, are of increasing concern to policymakers, practitioners, and advocates (Turner et al., 2006; Blank, 2007; Blank \& Kovak, 2008; Hetling, 2011; Loprest, 2011; Ovwigho et al., 2011; Moore et al., 2012). Many are worried about the well-being of children in these families and the ability of mothers to provide financially without employment or public cash assistance - the two most common sources of regular cash income.

Although women who are disconnected from work and welfare have little or no formal measured income, studies on consumption poverty indicate that the extreme poor do survive, often relying on nontraditional income, not captured in formal measures, such as gifts or the use of debt (Meyer \& Sullivan, 2003; 2006). A rich body of literature, guided by a number of key qualitative studies, provide an understanding of the income packaging strategies of low-income women, who often piece together cash and non-cash support from a variety of formal and informal sources (Edin \& Lien, 1997; Miranne, 1998; Smith et al., 2000). Studies indicate that combining and supplementing low-wage work and public cash assistance receipt is a common survival strategy among the working poor and welfare recipients (Edin \& Lein, 1997; Kalil \& Ryan, 2010; Pyles, 2007). Research on disconnected women echoes these findings (Blank \& Kovak, 2008; Seefeldt \& Horowski, 2012; Loprest \& Nichols, 2011). However, to date, literature on income packaging has not considered the different strategies among women in 


\section{INCOME PACKAGING AND ECONOMIC DISCONNECTION}

different circumstances and how state TANF policies may influence these approaches to economic survival.

The current research adds to our understanding of the economic survival strategies of disconnected women by investigating whether or not income-packaging strategies among disconnected women are similar or distinct from those of low-income women connected through welfare or work. The study compares the sources of support of the two groups while for controlling for the possible effects of state welfare policies and the local unemployment rate. An examination of the differences and similarities in sources of support is critical to designing programs and policies to better serve this at-risk group of women and connect them to services. On one hand, if disconnected women are underutilizing certain supports, for example aid from non-profit organizations, in comparison to connected women, better outreach may be warranted. On the other hand, if disconnected women are using more supports than connected women, these programs might be optimal venues to provide referrals to TANF agencies or job training programs appropriate for this group.

\section{Rise of Economic Disconnection among Low-Income Women}

The Personal Responsibility and Work Opportunities Reconciliation Act (PRWORA) of 1996 altered the approach the U.S. government takes towards assisting low-income families, replacing the previous entitlement program with Temporary Assistance for Needy Families (TANF). This new program changed the rules of participation, including the implementation of time limits, work requirements, and sanction rules for noncompliance. While initial data indicated success in moving families off assistance and into employment, data that are more recent indicate that lower numbers in terms of receipt has not correlated with significantly higher employment numbers or earnings (Hildebrandt \& Stevens, 2009). Studies of welfare leavers 


\section{INCOME PACKAGING AND ECONOMIC DISCONNECTION}

show that former clients became disconnected from work as well as welfare (e.g., Wood \& Rangarajan, 2003). This premature separation from assistance and failure to reconnect may be due to a variety of factors, including strict eligibility requirements, lack of transportation or access to the offices, the multiple visits and paperwork that must be completed, lack of information or misinformation, and social stigmas that surround public assistance (Currie, 2006; $\mathrm{Wu} \&$ Eamon, 2007). Some have speculated that stricter welfare rules directly affected the rise in economic disconnection as new rules coupled with worsening economic circumstances have increased the vulnerability of these women (Moore et al., 2012; Ovwigho et al., 2011).

Although the reasons for the increase in disconnected women are not fully understood, the rise in economic disconnection has been confirmed in numerous studies and with various national and state level datasets. Research has documented the rise in the proportion of disconnected women among low-income women from about one in ten in the mid-nineties to about one-quarter more recently (Blank \& Kovak, 2009; Loprest, 2003; Moore et al., 2012; Turner et al, 2006). Although exact estimates vary, the rise is universally demonstrated, and variation is attributed to methodological differences such as variations in location, timing, and calendar year (Loprest, 2011). Moreover, women may cycle in and out of economic disconnection and point-in-time studies may underestimate the extent of disconnection among low-income women (Marcenko et al, 2012).

\section{Income-Packaging by Disconnected Women and Sources of Support}

By definition, economically disconnected women rely on very little or no formal cash income. One state level study found that the average income of disconnected women is less than $\$ 500$ a month whereas former TANF recipients who are employed have more than $\$ 2,000$ a month (Moore et al., 2012). How this vulnerable population group maintains any level of well- 


\section{INCOME PACKAGING AND ECONOMIC DISCONNECTION}

being in light of having no traditional sources of income from formal employment or public cash assistance is thus a critical question.

The lack of formal cash income suggests that disconnected women rely heavily on family and friends for additional income or in kind gifts as well as public non-cash assistance, child-care assistance, and other unspecified support (Edin \& Lein, 1997; Moore et al., 2012). The use of public non-cash assistance, specifically Medicaid and Supplemental Nutrition Assistance Program (SNAP), is common (Blank \& Kovak, 2008, Marcenko et al., 2012). Disconnected women often live with family or friends with either cheap rent or rent-free housing (Moore et al., 2012; Kalil \& Ryan, 2010). Ovwigho and colleagues (2011) found a majority (57\%) of chronically disconnected women report some income, whether from another member's earnings, child support, or social security insurance (SSI). Through interviews with 100 disconnected families, Zedlewski and colleagues (2003) found that in-kind support like food, transportation, or child-care from family and friends as well as cash for food or rent is common, but that help is sometimes irregular. Other studies indicate that disconnected women sometimes work informally (Edin \& Lein, 1997; Zedlewski et al., 2003). Informal work strategies can include both illegal means of income, such as selling drugs or sex, or a legal means such as bartering or selling a service such as babysitting, pawning an item, or selling blood (Pyles, 2007).

Taken together this research indicates that disconnected women, like low-income women in general, utilize a variety of methods to "get by". However, often these strategies are unreliable or not significant enough to support them and their children (Ovwigho et al., 2011). The larger body of research on the income packaging strategies of low-income women informs recent research on disconnected women and provides details on possible sources of financial support. Considering the absence of formal cash income among disconnected women, we 


\section{INCOME PACKAGING AND ECONOMIC DISCONNECTION}

discuss three types of support, 1) public non-cash assistance, 2) help from family and friends, and 3) assistance from social service providers.

\section{Receipt of Public Non-Cash Assistance}

Public non-cash assistance programs, including vouchers and designated supports such as SNAP, health insurance programs, housing assistance, and child-care, would appear to be a potential and critical piece of income packaging strategies for low-income women, and research supports this hypothesis. Studies have shown a high reliance on these non-cash assistance programs, especially SNAP and other food subsidies, and Medicaid (Litt et al., 2000). Nonworking mothers rely on these forms of assistance particularly (Danziger et al., 2000). For example, SNAP participation has increased since 2007 during the recession, with roughly 46.6 million people, or 22.3 million households participating in 2012 (Food and Nutrition Services, 2013). Approximately, one in five low-income families use Medicaid (Wu \& Eamon, 2007), and, in 2008, health care programs such as Medicaid and SCHIP were "the most widely used among unwed mothers" (Kalil \& Ryan, 2010).

In contrast to the high prevalence of food and medical assistance, public housing and child-care are less commonly used supports among low-income households. An estimated ten percent of low-income households use housing assistance (Wu \& Eamon, 2007), but due to lack of supply, qualified individuals go without this support (Kalil \& Ryan 2010). Child-care assistance is another crucial, yet underutilized, support (Zedlewski et al, 2003) Women often patch together various methods of child care because funding is limited, eligibility and administrative processes can be complicated, and provider availability limit women's ability to find consistent, quality, and stable child-care (Scott et al., 2005). Recent studies have also shown a decrease in public non-food support in the past decades (Danziger, 2010). Moreover, even 


\section{INCOME PACKAGING AND ECONOMIC DISCONNECTION}

when utilized, public non-cash assistance is not always sufficient to meet a family's needs and most former TANF recipients rely on public or private sources of help (Hollar, 2003).

\section{Help from Family and Friends}

Research indicates help from family and friends is an important source of support for low-income mothers (Danziger et al., 2000; Edin \& Lein, 1996; Hollar, 2003; Litt et al., 2000). These private sources of support come in various forms including cash assistance, in-kind assistance, and instrumental assistance (Kalil \& Ryan, 2010). Presents for children, household items, and money as a gift are the most prevalent forms of private support (Kalil \& Ryan, 2010). Instrumental assistance, such as emergency child-care, transportation, and sometimes rent-free or reduced rent housing, is another important way family and friends provide support (Edin \& Lein, 1997; Scott et al., 2005). Low-income mothers also sometimes receive money from their child's father, either through child support payments or direct cash to the mother, but these too can be sporadic and not a regular source of income (Edin \& Lein, 1997). Although such gifts and help are often small in terms of cash, such support can mitigate the threat of homelessness and thus are critically important to family well-being (Harknett, 2006; Henly et al., 2005; Passero et al., 1991). Recent data also indicates that private help is particularly important to certain groups of at-risk women including those with larger families, lower educational levels, and depressive symptoms as well as those who report no public assistance (Harknett, 2006). Support from Non-Profits and Social Service Providers

The last area which low-income and disconnected women may find assistance is from non-profits or other social service providers. Non-profits, charities, and social service providers have responded to many of the holes in the public safety net (Daponte, 2000; Lynn, 2002; Marwell, 2004). They often provide material assistance, such as job training, child-care, housing 


\section{INCOME PACKAGING AND ECONOMIC DISCONNECTION}

or shelter assistance, and food assistance programs. However, the role of non-profits has stayed stable for those experiencing material hardship even though there has been an increase in need since the mid-1990s (Guo, 2009). Low-income women often fail to use non-profits due to various reasons including that many specialize in serving the neediest populations (Guo, 2009;

Kissane, 2003). Along with limited numbers of households receiving assistance from non-profits, few households received help from non-profits and government programs at the same time (Guo, 2009). Low-income households turn to non-profits and other social service providers when they do not qualify for government assistance or when government assistance and private support networks cannot meet their needs (Ahluwalia et al., 1998; Edin \& Lein, 1997; Wu \& Eamon, 2007; Zedlewski et al, 2003). They have been particularly important to groups who are ineligible for public benefits, such as certain groups of immigrants (Moretti \& Perloff, 2000).

\section{Current Study}

Although much research has focused on survival strategies of low-income women, and recently of disconnected women as well, questions on how the survival strategies of these two groups compare to each other remain. An understanding of the similarities or differences can help inform how programs could more effectively target vulnerable groups to deliver needed services. The analyses were guided by two research questions. First, what financial and in-kind supports are used by disconnected women in comparison to other low-income women? Second, what is the relationship between supports and economic disconnection, controlling for state TANF rules and the local unemployment rate?

\section{Methods}

\section{Sample and Data Sources}




\section{INCOME PACKAGING AND ECONOMIC DISCONNECTION}

The study's sample comes from adult well-being modules of the 1996, 2001 and 2004 panels of the Survey of Income and Program Participation (SIPP) and includes mothers residing in households below 200 percent of the poverty line. The study universe was restricted to women who were between the ages of 18 and 54 at the start of the panel, who were the designated parent of at least one child, and reported being never married, divorced, separated, or widowed.

Study variables came from three different data sources and were merged together to create a comprehensive analytical file. First, the main data source for the project was the restricted-use, confidential, micro-level version of the SIPP, made available at the New York Census Research Data Center at Baruch College, a secure laboratory, operated in partnership with the U.S. Census Bureau's Center for Economic Studies. The Research Data Center (RDC) version of the SIPP includes codes for all states as well as county identification and thus enabled the merging of variables measuring state welfare rules data and county unemployment rates into the analytical dataset. Although geographic information in the public-use SIPP data is available on the state level, some of the less populated states are grouped and coded together and county level identification is not available.

All individual level variables also come from the SIPP, a longitudinal panel study that provides a comprehensive picture of income and program participation among US residents and, beginning with the 1996 redesign, over-samples families residing in high poverty concentration areas. The central focus of the data is economic and demographic, with substantial detail on income sources and amounts, employment, public assistance participation, family composition, and residential location. In addition to the core questions that are asked of SIPP members every four months (every wave), the survey includes topical modules asked once or twice over the course of the panel. This project made use of the adult wellbeing module, which includes 


\section{INCOME PACKAGING AND ECONOMIC DISCONNECTION}

variables measuring need and "who helped" with particular hardships. Specifically, a series of question sets, each addressing a particular household expense (such as rent or mortgage, utility

bills, and medical care) asks first if the household experienced that need, second if the household paid for the need, and third who if anyone helped with the expense. Possible responses for the "who helped" questions are family member or relative, friend or neighbor, department of social service, church or nonprofit group, and other. The adult wellbeing module is asked in wave 8 of the 1996 and 2001 panels and during wave 5 of the 2004 panel.

Second, state level data for the project came from the Welfare Rules Database (WRD), a longitudinal database of state-specific TANF rules maintained by the Urban Institute and funded by the US Department of Health and Human Services Administration for Children and Families and Assistant Secretary for Program Evaluation. The database contains information on TANF rules for all 50 states and DC as coded from state caseworker manuals and updates. The data is then reviewed and verified by state officials. The project used data from 1998, 2003, and 2005, to match the timing of the adult wellbeing modules of the three SIPP panels.

Lastly, county unemployment rates were taken from the Department of Labor, Local Area Unemployment Statistics. The variables were merged by county and year, specifically 1998, 2003, and 2005.

\section{Key measures}

\section{Economic Disconnection}

Sample members were divided into four analytical groups based on the amount of time that they were economically disconnected during the panel. Economic disconnection was defined as the absence of TANF, employment income, and SSI. Those who reported at least one of these sources of income in all waves of the panel are in the connected group. At the other end of the 


\section{INCOME PACKAGING AND ECONOMIC DISCONNECTION}

spectrum, those who were without any of these sources in at least half of the waves were defined as long-term disconnected. Women who experienced disconnection for more than a quarter but less than half of the waves were grouped as medium-term disconnected, and those who were disconnected less than a quarter of the waves were termed short-term disconnected.

\section{Private and Public Non-Cash Supports}

A dichotomous variable indicating support from family, friends, or a church or non-profit group was created using a number of variables from the adult wellbeing module. First, three separate variables were created, one each for help from family, friends, or a church or non-profit group. All three variables included help received for rent or mortgage, eviction, utility payments, restoring utilities, or medical or dental visits. Individuals who received help from one or more of the three private sources for any reason were coded as receiving private support.

Similarly, a variable measuring all types of public non-cash supports was created based on a number of variables in the core questionnaire on the receipt of public benefits. The created variable is dichotomous and equals one if at least one person in the household received at least one type of public non-cash benefit. These benefits included free or reduced lunch or breakfast; energy assistance; Women, Infants, and Children (WIC); SNAP; Medicaid; and housing assistance.

\section{Analytic strategy and models}

Research began with a descriptive examination of the use of supports by analytical group. This profile provides a critical overview of the experiences and differences among the groups without controlling for other factors. The bivariate analysis was used to inform model construction, but the findings themselves are also informative on their own in terms of policy implications and are described below in the results section. 


\section{INCOME PACKAGING AND ECONOMIC DISCONNECTION}

Logistic and multilevel regression models then examined separately the influence of being disconnected on type of supports and then the influence of support types on being disconnected. In both cases, the examination was first limited to the inclusion of variables on the individual level, and thus logistic models were employed. As the model became more complicated and state and county level variables were included, multilevel logistic models were utilized. Previous methods of combining variables at different levels have been shown to produce standard errors that are biased downward because often the errors across micro units with the same macro group are not random (Moulton, 1990). In multilevel modeling, the technique is designed to examine effects at multiple levels. The present analyses uses Maximum Likelihood estimations to produce efficient estimates (Hox, 2002; Luke, 2004). In this case, the model better examines the relative importance of state, county, and individual level effects.

Investigations first addressed how economic disconnection, and specifically the proportion of time one is disconnected, may influence one's use of private support and public non-cash support. Two models were constructed and then applied to each outcome, private versus public supports, separately. Logistic regression models were based on variations of the following basic framework:

Support type [Logistic regression] $=\beta_{\mathrm{o}}+\beta_{1} \mathrm{I}_{\mathrm{i}}+\beta_{2} \mathrm{~F}_{\mathrm{i}}+\beta_{3} \mathrm{~S}_{\mathrm{i}}+\beta_{4} \mathrm{U}_{\mathrm{i}}+\beta_{5} \mathrm{P}_{\mathrm{i}}+\varepsilon_{\mathrm{i}}$ Where:

- $\quad \mathrm{I}=$ A vector of personal characteristics including disconnected status, race, age, marital status, education level, student status, and disability status,

- $\quad \mathrm{F}=\mathrm{A}$ vector of family characteristics including number of children metro residence, and household members

- $\mathrm{S}=$ a vector of variables that specify the state TANF rules, 


\section{INCOME PACKAGING AND ECONOMIC DISCONNECTION}

- $\mathrm{U}=$ county unemployment rate,

- $\quad \mathrm{P}=$ panel dummy variables to control for changes in unobserved trends over time.

Individual and family level variables included both demographic characteristics as well

as variables considered risk factors for disconnection such as disability status and low-education

level. Three measures of state TANF rules were included in that vector. First, we include the average TANF grant for a family of three based on the assumption that grant amounts may affect decisions to apply for welfare. Second, disconnected women may be discouraged to apply for welfare based on diversion programs and strategies (Fender, Signe, and Berstein, 2002). We thus include a dummy variable measuring whether or not a state has a formal cash diversion program. Third, disconnected women may separate from the welfare program prematurely (without employment) based on how strict or lenient a state may be in terms of time limit and sanction rules and granting extensions or exemptions from certain requirements. Because there are a great number of rules related to exemptions and exceptions to rules, we employ the flexibility index designed by Fellowes and Rowe (2004). The index is made up of twelve related variables measuring state rules regarding work activity and sanction leniency (p. 371). Finally, the model includes the county unemployment rate, which may affect one's ability to find employment, and a control for the year of the panel.

The possibility that the types of supports available to women may influence economic disconnection was then examined using another series of regression models. First, we examined the effect of support types on economic disconnection without regards to the amount of time spent in the disconnected state. Second, we applied the same models to explain long-term disconnection as the dependent variable. In both cases, the modeling began with a null model with included only the types of support used and controls for panel year. The second model 
INCOME PACKAGING AND ECONOMIC DISCONNECTION

included the individual and family variables previously explained, and the final model, estimated with multi-level logistical regression, included the three state TANF rules and the county unemployment rate.

\section{Results}

\section{Descriptive Portraits of Connected and Disconnected Women}

Table 1 shows the characteristics of the 5,754 sample members as a whole as well as by the four analytic groups: long-term disconnection, medium-term disconnection, short-term disconnection, and those who were connected in all waves. The mean age for participants was 31 years old at the beginning of the panel. A majority of participants was White $(56.5 \%)$ and never married (52.7\%), and these are fairly consistent when considering disconnected status. Forty percent of the sample members have a high school diploma or equivalent, and about 13 percent have a work limiting disability. This percent ranges from 20 percent among long-term disconnected women to 10 percent of connected women, with about 15 percent of both mediumterm and short-term disconnected women experiencing a work limiting disability. The average number of children is two, and a large majority (83\%) live in a metro area whether or not they are disconnected for any period of time. A little less than 20 percent are full-time or part-time students. About 68 percent of the full sample lives alone, 23 percent reside with related family, and 10 percent reside with unrelated family. Participants who were medium and short-term disconnected were more likely to live alone ( $74 \%$ for medium-term and $75 \%$ for short-term), $68 \%$ of long-term disconnected women lived alone, and $65 \%$ of connected women lived alone. Among those who lived with related family, connected women were most likely to live with family (31\%), followed by long-term disconnected (23\%), then short-term, and medium-term (17 and $13 \%$ respectively). Fifteen percent of medium-term disconnected women lived with 


\section{INCOME PACKAGING AND ECONOMIC DISCONNECTION}

unrelated family; whereas only 10 percent of short-term and 8 percent of long-term lived with unrelated family. Only six percent of connected women lived with family.

Insert Table 1 about here.

Among the full sample, 83 percent of the participants relied on some form of public noncash assistance. Slightly more long-term disconnected women used public non-cash assistance $(87 \%)$, in comparison to 83 percent of medium and short-term disconnected women and 82 percent of connected women. Considering the receipt of private assistance, fewer women in general used this form of help. Eleven percent of the full sample used private assistance, and disaggregating this, about one out of five (18\%) long-term disconnected women used private assistance in comparison to 14 percent of medium-term disconnected, and 10 percent of shortterm disconnected women used private assistance. Only eight percent of connected women reported any form of private assistance.

\section{Explaining Income Packaging Strategies by Disconnected Status}

\section{Use of Private Supports}

The first two column of Table 2 presents the results of two logistic models with receipt of private help as the dependent variable. Model 1 demonstrates the odds that one will use private help controlling only for individual and family level characteristics, and Model 2 includes state and county level variables as well. Model 1 indicates that four variables are statistically significant in explaining the use of private support. If a participant was disconnected more than $50 \%$ of the time, they were two times more likely to report private help than low-income, connected women. Women were also about two times more likely to receive private help if they also were receiving public non-cash support. Disabled women had 1.6 times the odds of using private help compared to those without a work-limiting disability. Finally, residing with related 


\section{INCOME PACKAGING AND ECONOMIC DISCONNECTION}

family was also positively associated with the use of private help at a statistically significant level. The addition of state level variables and county unemployment in Model 2 produces very little change in the impact of individual variables, with all four variables leading to similar odds of seeking private help. Additionally, sample members of the 2004 panel were more likely to report private help than members of the 1996 panel. None of the macro level variables are statistically significant. However, the random effects intercepts for the state and county levels are statistically significant indicating that unmeasured characteristics on those levels are related to the dependent variable.

Insert Table 2 about here.

\section{Use of Public Non-Cash Supports}

Table 2 also presents the results of the two logistic models with the receipt of public noncash assistance as the dependent variable, with Model 3 focused on the influence of individual level variables and Model 4 also including state and county level variables. Women who reported private help had more than two times the odds of using public non-cash support; this was true for both Model 3 and 4. Black and Latina participants were more likely to use public help than their White counterparts (more than 2 times more likely for Black participants and less than 2 times more likely for Latina participants). The addition of state level variables, however, decreased this slightly (to odds ratios of 2.13 and 1.57 respectively). Sample members with some college education were significantly less likely than those with a high school diploma or equivalent to use public non-cash benefits in both models. A work-limiting disability increased the odds of using public help by almost four times (3.75 in Model 1 and 3.58 in Model 2). The number of children was also positively related to public non-cash benefit receipt with the odds of receipt increasing with each additional child. Women who lived in a metro area were less likely 


\section{INCOME PACKAGING AND ECONOMIC DISCONNECTION}

to use public non-cash benefits than women who do not. In both models, those who reside with related family are less likely to receive public non-cash benefits than those who live alone. The 2004 panel members were 1.8 times more likely than the 1996 panel to seek public non-cash help in both models. Finally, as the unemployment rate rises, women are significantly more likely to use public non-cash help.

\section{Explaining Disconnection by Types of Supports}

Because the direction of causation in the relationship between disconnection and income packaging strategies is not clear, we also investigated economic disconnection as the dependent variable. Table 3 presents the results of the six logistic models explaining economic disconnection as function of the type of support received. The first three models examine the influences on economic disconnection, regardless of the amount of time spent disconnected. The last three models examine long-term disconnection specifically.

Insert Table 3 about here.

\section{Economic Disconnection}

In Table 3, we first examine whether or not types of support influence economic disconnection generally. Model 1, which controls only for types of supports received, indicates that those who receive any private help are 1.7 times more likely to be disconnected. In Model 2, where personal characteristics are taken into account, those who receive private help continue to be more likely to be disconnected although less so with 1.45 the odds of those without private support. This increased risk remains constant in Model 3, which includes controls for macro level variables. In both Models 2 and 3, Latina participants are less likely to be disconnected for any period of time than their White counterparts, and Black participants had no significant increase or decrease in their likelihood. Disabled women were 1.5 times more likely to be 


\section{INCOME PACKAGING AND ECONOMIC DISCONNECTION}

disconnected than those without a disability were. Participants who resided with related family were less likely to be disconnected than those who lived alone (with odds ratio of 0.27 in Model 2 and Model 3), but those who lived with unrelated family increased their likelihood of disconnection by more than 2 times in both models. In all three models, the likelihood of being disconnected is greater for women from the 2001 to 2004 panels compared with the 1996 panel. Finally, none of the state welfare variables or the county unemployment rate are statistically significant, but the significant random effects intercepts indicate that variation on those level influence disconnected status.

\section{Long-term Economic Disconnection}

The last three models in Table 3 present the results of the three logistic models with longterm economic disconnection as the dependent variable. In all three models, use of any private help increases the odds of long-term disconnection by two times, although Model 5 and 6 are slightly less (with approximate odds ratios of 1.8). Again, being disabled increases the odds of long-term disconnection, and controlling for macro level variables in Model 6 increases the ratio from 1.53 to 1.63 . Similar to the models of general economic disconnection, participants who reside with related family are less likely to experience long-term economic disconnection than those living alone. Those residing with unrelated family were almost three times more likely to experience long-term disconnection than those living alone in Model 5, but when state level variables were taken into consideration in Model 6, the odds ratio falls to 1.56. Both the 2001 and 2004 panels showed a statistically significant increased likelihood for long-term economic disconnection in all three models. Similar to the results of Model 3, although the four macro level variables were not statistically significant, the significant random effects intercepts indicate that variation on those level influence long-term disconnection. 
INCOME PACKAGING AND ECONOMIC DISCONNECTION

\section{Discussion and Conclusion}

The project's estimates provide important insights into how disconnected women, an economically vulnerable population, maintain any level of well-being in light of having no cash income from formal employment or public assistance. Specifically, findings indicate the importance of help from private sources. The descriptive portrait shows that support from all three sources of private help, family, friends, and community groups, is more prevalent among economically disconnected women, especially those who are disconnected more than half of the time. Considering the regression models explaining types of support, results show that disconnection is not related to an increased likelihood of receiving public non-cash supports. However, disconnection is a significant influence of private support receipt. When we examine the correlation in the reverse causal order, the models indicate that support from private sources (including family, friends, and non-profit agencies) is a significant predictor of disconnection, and that the impact is stronger when examining long-term economic disconnection.

Although not the focus of our inquiry, results related to household composition are very interesting. Our analysis focused on disconnected single mothers in three types of household arrangements. Descriptively, we found that disconnected women were more likely to live alone than their connected counterparts. Regression models provide results that are more complex and support the need for additional research on cohabitation, household resource sharing, and economic disconnection. On one hand, living with related family decreases both economic disconnection and reliance on other income packaging strategies indicating that the disconnected mother and her children may be receiving the help they need from household members. On the other hand, living with unrelated family increases the odds of economic disconnection notably, 


\section{INCOME PACKAGING AND ECONOMIC DISCONNECTION}

but does not influence the use of public non-cash benefits and only slightly decreases the use of private supports indicating that these families are still in need of other help.

The project is limited by two critical characteristics of the data. First, our measurement of private supports likely underestimates the true use of help from private sources. The SIPP adult well-being module asked about specific large emergency needs and who helped in those circumstances, but did not ask about the use of food banks or clothing donations in a similar manner. Thus, the use of those types of help is not included in our measure. Second, the crosssectional nature of the data makes conclusions about causality impossible. Because the adult well-being module is asked only once during the panel, we were unable to examine whether becoming disconnected motivates women to find additional resources or whether having access to other resources influences decisions to not to pursue employment or welfare. Future research on the dynamics of disconnection considering the role of private help is particularly needed, as is additional research on a broader definition of private help.

The findings, although associative, do have strong policy implications regarding potential outreach to disconnected women. First, the strong association between economic disconnection and use of private assistance indicates that-profits and community groups, along with family and friends, may be potential venues for outreach to disconnected women. Second, although disconnected women are not less likely to receive public non-cash assistance, they are not more likely either. With lower incomes, the logical assumption is that disconnected women are needier and should be more likely to receive public supports like SNAP. Perhaps sanctioned and diverted clients are not receiving the non-cash benefits for which they are untitled. Finally, our findings that 2001 and particularly 2004 sample members have increased odds of disconnection as well as the use of supports emphasizes the need for increasing attention to these issues. 
INCOME PACKAGING AND ECONOMIC DISCONNECTION

\section{References}

Acs, G., \& Loprest P. (2004). Leaving Welfare: Employment and Well-Being of Families that Left Welfare in the Post-Entitlement Era. Kalamazoo, MI: W.E. Upjohn Institute for Employment Research.

Ahluwalia, I. B., Dodds, J. M., \& Baligh, M. (1998). Social Support and Coping Behaviors of Low-Income Families Experiencing Food Insufficiency in North Carolina. Health Education \& Behavior. 25, 599-612.

Blank, R. M. (2007). Improving the safety net for single mothers who face serious barriers to work. The Future of Children, 17(2), 183-197.

Blank, R. \& Kovak, B. (2008). The Growing Problem of Disconnected Single Mothers. National Poverty Center Working Paper Series \#07-28.

Currie, J. (2006). “The Take-up of Social Benefits,” in Auerbach, A., Card, D., \& Quigley, J., eds., Poverty, The Distribution of Income, and Public Policy. New York: Russell Sage.

Danziger, S. (2010). The Decline of Cash Welfare and Implications for Social Policy and Poverty. Annual Review of Sociology. 36(1). 523-545.

Danziger, S., Corcoran, M., Danziger, S., \& Heflin, C. M. (2000). Work, income, and material hardship after welfare reform. The Journal of Consumer Affairs. 24, 6-30.

Daponte, B. O. (2000). Private versus public relief: Use of food pantries versus food stamps among poor households. Journal of Nutrition Education. 32, 72-83.

Edin, K., \& Lein, L. (1997). Work, Welfare, and Single Mothers' Economic Survival Strategies. American Sociological Review. 62(2). 253-266. 


\section{INCOME PACKAGING AND ECONOMIC DISCONNECTION}

Food and Nutrition Services. (2013). Supplemental Nutrition Assistance Program: Monthly Data. United States Department of Agriculture. Web: accessed July 16, 2013. http://www.fns.usda.gov/pd/34SNAPmonthly.htm

Guo, B. (2010). Beyond the public safety net: The role of nonprofits in addressing material hardship of low-income households. Nonprofit and Voluntary Sector Quarterly, 39(5), 784-801.

Harknett, K. (2006). The relationship between private safety nets and economic outcomes among single mothers. Journal of Marriage and Family, 68(1), 172-191.

Henley, J. R., Danziger, S. K., \& Offer, S. (2005). The contribution of social support to the material well-being of low-income families. Journal of Marriage and Family. 67, 122140.

Hetling, A. (September, 2011). The Importance of Region and State Welfare Rules for Disconnected Single Mothers. University of Kentucky Center for Poverty Research Discussion Paper Series, DP2011-04.

Hildebrandt, E., \& Stevens, P. (2009). Impoverished Women with Children and No Welfare Benefits: The Urgency of Researching Failures of the Temporary Assistance for Needy Families Program. American Journal of Public Health. 99(5). 793-801.

Hox, J. 2002. Multilevel Analysis: Techniques and Applications. Mahwah, NJ: Lawrence Erlbaum Associates, Publishers.

Kalil, A., \& Ryan, R. M. (2010). Mothers' economic conditions and sources of support in fragile families. The Future of Children, 20(2), 39-61.

Kissane, R. J. (2003). What's Need Got to Do with It? Carriers to Use of Nonprofit Social Services. Sociology and Social Welfare. 30(2). 127. 


\section{INCOME PACKAGING AND ECONOMIC DISCONNECTION}

Litt, J., Gaddis, B. J., Fletcher, C. N., \& Winter, M. (2000). Leaving welfare: Independence or continued vulnerability? The Journal of Consumer Affairs. 34. 82-96.

Loprest, P., \& Zedlewski, S. (2006). The Changing Role of Welfare in the Lives of Families with Children. Assessing the New Federalism Occasional Paper Number 73. Washington, DC: The Urban Institute.

Loprest, P. (2011). Disconnected families and TANF. Washington, DC: The Urban Institute. Temporary Assistance for Needy Families Program—Research Synthesis Brief, 2.

Loprest, P., \& Nichols, A. (2011). The Dynamics of Being Disconnected from Work and Welfare. Washington, DC: The Urban Institute.

Luke, D. A. 2004. Multilevel Modeling. Series: Quantitative Aplications in the Social Sciences \# 143. Thousand Oaks, CA: Sage Publications.

Lynn, L. E. (2002). Social services and the state: The public appropriation of private charity. Social Service Review. 76, 58-82.

Marcenko, M. O., Hook, J. L., Romich, J. L., \& Lee, J. S. (2012). Multiple Jeopardy: Poor, Economically Disconnected, and Child Welfare Involved. Child Maltreatment. 00(0). 112.

Marwell, N. P. (2004). Privatizing the welfare state: Nonprofit community-based organizations as political actors. American Sociological Review. 69, 265-291.

Miranne, K. B. (1998). Income Packaging as a Strategy for Welfare Mothers. Affilia, 13, 211-32.

Moore, Q., Wood, R. G., \& Rangarajan, A. (2012). The Dynamics of Women Disconnected from Employment and Welfare. Social Service Review, 86(1), 93-118.

Moretti, E., \& Perloff, J. M. (2000). Use of public transfer programs and private aid by farm workers. Industrial Relations. 29, 26-47. 


\section{INCOME PACKAGING AND ECONOMIC DISCONNECTION}

Ovwigho, P., Kolupanowich, N. J., Hetling, A., \& Born, C. E. (2011). Lost Leavers: Uncovering the Circumstances of Those Without Welfare and Without Work. Families in Society. 92(4). 397-404.

Passero, J. M., Zax, M., \& Zozus, R. T. (1991). Social network utilization as related to family history among the homeless. Journal of Community Psychology. 19, 70-78.

Pyles, L. (2007). Measuring the informal economy: a validation study of the resource generating strategies scale. Research on Social Work Practice, 17(4), 466-473.

Scott, E. K., London, A. S., \& Hurst, A. (2005). Instability in patchworks of child care when moving from welfare to work. Journal of Marriage and Family,67(2), 370-386.

Seefeldt, K. \& Horowski, M. (2012). The Continuum of Connection: Low-income Families and Economic Support during the Great Recession. National Poverty Center Working Paper Series \#12-11.

Wood, R. G. \& Rangarajan, A. (2003). What's Happening to TANF Leavers Who Are Not Employed? Mathematica Policy Research, Inc. Issue Brief 6.

Wu, C. F., \& Eamon, M. (2007). Public and private sources of assistance for low-income households. Journal of Sociology \& Social Welfare, 34, 121.

Zedlewski, S. R., S. Nelson, K. Edin, H. Koball, K. Pomper, \& T. Roberts. (2003). Families Coping Without Earnings or Government Cash Assistance. Assessing the New Federalism Occasional Paper Number 64. Washington, DC: The Urban Institute. 
Table 1. Sample Description

\begin{tabular}{|c|c|c|c|c|c|}
\hline & $\begin{array}{l}\text { Full } \\
\text { Sample }\end{array}$ & $\begin{array}{l}\text { Long } \\
\text { Term } \\
\end{array}$ & $\begin{array}{l}\text { Medium } \\
\text { Term }\end{array}$ & $\begin{array}{l}\text { Short } \\
\text { Term }\end{array}$ & $\begin{array}{l}\text { Connecte } \\
\text { d }\end{array}$ \\
\hline Average age at beginning of panel & $\begin{array}{l}31.43 \\
(8.92)\end{array}$ & \begin{tabular}{|l|}
32.8 \\
$(8.35)$ \\
\end{tabular} & $\begin{array}{l}30.93 \\
(8.4)\end{array}$ & $\begin{array}{l}31.67 \\
(8.6)\end{array}$ & $\begin{array}{l}31.16 \\
(9.26)\end{array}$ \\
\hline \multicolumn{6}{|l|}{ Race } \\
\hline White & 58.5 & 61.8 & 57 & 58 & 58.3 \\
\hline Black & 35.9 & 32.3 & 37.2 & 38 & 35.4 \\
\hline Latina & 21.3 & 16.1 & 17.4 & 19.2 & 24.3 \\
\hline Other & 5.6 & 6 & 5.9 & 3.9 & 6.1 \\
\hline Martial Status - Never Married & 52.7 & 46.7 & 54.4 & 49.8 & 54.7 \\
\hline \multicolumn{6}{|l|}{ Education level } \\
\hline Less than high school & 22 & 22.2 & 23.8 & 20.8 & 22 \\
\hline High school grad or GED & 39.6 & 40.3 & 39.6 & 39.7 & 39.4 \\
\hline At least some college & 38.4 & 37.5 & 36.7 & 39.4 & 38.7 \\
\hline Work limiting disability & 13.3 & 20.1 & 14.9 & 15 & 10.7 \\
\hline Number of children under 18 in family & $\begin{array}{l}2.09 \\
(1.81)\end{array}$ & & $2.04(1.1)$ & $\begin{array}{l}2.06 \\
(1.18)\end{array}$ & $\begin{array}{l}2.14 \\
(1.21)\end{array}$ \\
\hline Metro residence & 83.2 & 80.4 & 82.8 & 82.7 & 84.1 \\
\hline Full or part-time student & 18.6 & 13.2 & 16.8 & 17 & 20.9 \\
\hline Lives alone & 68.4 & 71.6 & 74.2 & 74.6 & 64.8 \\
\hline Resides with related family & 22.8 & 22.5 & 13.3 & 16.7 & 31.1 \\
\hline Resides with unrelated family & 10.2 & 7.6 & 14.5 & 10.4 & 6.3 \\
\hline & & & & & \\
\hline \multicolumn{6}{|l|}{ Public assistance - non-cash benefits } \\
\hline Food Stamps & 38.7 & 51.9 & 48.4 & 41.5 & 32.2 \\
\hline Medicaid & 40 & 48.8 & 49.4 & 41.5 & 34.8 \\
\hline WIC & 3.7 & 6.2 & 5.3 & 3.5 & 2.8 \\
\hline Energy assistance & 5.7 & 7.9 & 7.3 & 6.7 & 4.8 \\
\hline Housing assistance & 18.9 & 25.9 & 23.6 & 17.8 & 16.5 \\
\hline School lunch & 67.2 & 68.9 & 62.9 & 65.9 & 68.5 \\
\hline School breakfast & 42.1 & 47.6 & 42.2 & 41.1 & 41.1 \\
\hline Summary - any public non-cash assistance & 82.9 & 87.1 & 83.4 & 82.5 & 82 \\
\hline \multicolumn{6}{|l|}{ Private assistance } \\
\hline Ability to meet essential expenses & 39.4 & 46 & 42.1 & 44.2 & 35.4 \\
\hline Any private assistance from family & 6.9 & 12.6 & 11 & 6.7 & 4.6 \\
\hline Any private assistance from friends & 2.1 & 3.9 & 2.7 & 1.9 & 1.7 \\
\hline $\begin{array}{l}\text { Any private assistance from non-profit } \\
\text { organizations }\end{array}$ & 2.8 & 4.3 & 2.6 & 2.4 & 2.6 \\
\hline Summary - any private assistance & 10.5 & 17.9 & 13.6 & 10.4 & 8 \\
\hline $\mathrm{n}$ - unweighed & 5754 & 730 & 767 & 1179 & 3078 \\
\hline $\begin{array}{l}\text { Proportion estimation -weighted by final } \\
\text { person weight }\end{array}$ & & $12.09 \%$ & $13.40 \%$ & $21.21 \%$ & $53.30 \%$ \\
\hline
\end{tabular}


INCOME PACKAGING AND ECONOMIC DISCONNECTION

Table 2. Logistic Regression Models Explaining the Use of Private and Public Non-Cash

Supports $(\mathrm{n}=\mathbf{5 , 7 5 4})$

\begin{tabular}{|c|c|c|c|c|}
\hline \multirow{2}{*}{ Variable } & \multicolumn{2}{|c|}{ Use of Private Supports } & \multicolumn{2}{|c|}{$\begin{array}{c}\text { Use of Public Non-Cash } \\
\text { Supports }\end{array}$} \\
\hline & Model 1 & Model 2 & Model 1 & Model 2 \\
\hline \multicolumn{5}{|l|}{ Fixed Effects } \\
\hline \multicolumn{5}{|l|}{$\begin{array}{l}\text { Disconnected status (comparison } \\
\text { group = always connected) }\end{array}$} \\
\hline Fewer than $25 \%$ & $\begin{array}{l}1.19 \\
(0.16)\end{array}$ & $\begin{array}{l}1.21 \\
(0.15)\end{array}$ & \begin{tabular}{|l|}
0.98 \\
$(0.10)$ \\
\end{tabular} & $\begin{array}{l}0.96 \\
(0.10)\end{array}$ \\
\hline Between $25 \%$ and $50 \%$ & $\begin{array}{l}1.57 * * \\
(0.22)\end{array}$ & $\begin{array}{l}1.56^{* *} \\
(0.21)\end{array}$ & \begin{tabular}{|l|}
0.94 \\
$(0.12)$ \\
\end{tabular} & $\begin{array}{l}1.00 \\
(0.13)\end{array}$ \\
\hline More than $50 \%$ & $\begin{array}{l}2.05^{* * *} \\
(0.28)\end{array}$ & $\begin{array}{l}2.12 * * * \\
(0.27)\end{array}$ & $\begin{array}{l}1.16 \\
(0.16)\end{array}$ & $\begin{array}{l}1.13 \\
(0.16)\end{array}$ \\
\hline Any Public Non-Cash Support & $\begin{array}{l}2.21 * * * \\
(0.38)\end{array}$ & $\begin{array}{l}2.27 * * * \\
(0.37) \\
\end{array}$ & & \\
\hline Any Private Support & & & \begin{tabular}{|l|}
$2.24 * * *$ \\
$(0.39)$ \\
\end{tabular} & $\begin{array}{l}2.27 * * * \\
(0.37)\end{array}$ \\
\hline \multicolumn{5}{|l|}{ Race $($ comparison group $=$ White) } \\
\hline Black & $\begin{array}{l}0.89 \\
(0.10)\end{array}$ & $\begin{array}{l}0.95 \\
(0.11)\end{array}$ & \begin{tabular}{|l|}
$2.24 * * *$ \\
$(0.24)$ \\
\end{tabular} & $\begin{array}{l}2.13 * * * \\
(0.22)\end{array}$ \\
\hline Latina & $\begin{array}{l}0.71^{*} \\
(0.10)\end{array}$ & $\begin{array}{l}0.66^{* *} \\
(0.10)\end{array}$ & $\begin{array}{l}1.92 * * * \\
(0.23) \\
\end{array}$ & $\begin{array}{l}1.57 * * * \\
(0.20)\end{array}$ \\
\hline Other race & $\begin{array}{l}0.77 \\
(0.16)\end{array}$ & $\begin{array}{l}0.96 \\
(0.19)\end{array}$ & $\begin{array}{l}1.72 * * \\
(0.34)\end{array}$ & $\begin{array}{l}1.67 * * \\
(0.31)\end{array}$ \\
\hline Age & $\begin{array}{l}0.98^{*} \\
(0.01)\end{array}$ & $\begin{array}{l}0.98^{*} \\
(0.01)\end{array}$ & $\begin{array}{l}1.00 \\
(0.01)\end{array}$ & $\begin{array}{l}1.00 \\
(0.01)\end{array}$ \\
\hline Never Married & $\begin{array}{l}0.89 \\
(0.10)\end{array}$ & $\begin{array}{l}0.84 \\
(0.09)\end{array}$ & $\begin{array}{l}1.38^{* *} \\
(0.15)\end{array}$ & $\begin{array}{l}1.38 * * \\
(0.14)\end{array}$ \\
\hline \multicolumn{5}{|l|}{$\begin{array}{l}\text { Education (comparison group }=\mathrm{HS} \\
\text { grad or equivalent) }\end{array}$} \\
\hline Less Than High School & $\begin{array}{l}0.97 \\
(0.13)\end{array}$ & $\begin{array}{l}0.93 \\
(0.12)\end{array}$ & \begin{tabular}{|l|}
1.18 \\
$(0.15)$ \\
\end{tabular} & $\begin{array}{l}1.25 \\
(0.15) \\
\end{array}$ \\
\hline Some College & $\begin{array}{l}0.96 \\
(0.10)\end{array}$ & $\begin{array}{l}1.00 \\
(0.11)\end{array}$ & $\begin{array}{l}0.69 * * * \\
(0.06) \\
\end{array}$ & $\begin{array}{l}0.70 * * * \\
(0.06)\end{array}$ \\
\hline Work-limiting Disability & $\begin{array}{l}1.59 * * * \\
(0.19)\end{array}$ & $\begin{array}{l}1.49^{* *} \\
(0.18)\end{array}$ & \begin{tabular}{|l|}
$3.75^{* * *}$ \\
$(0.63)$ \\
\end{tabular} & $\begin{array}{l}3.58 * * * \\
(0.57)\end{array}$ \\
\hline $\begin{array}{l}\text { Number of Children Under } 18 \text { in } \\
\text { Family }\end{array}$ & $\begin{array}{l}1.01 \\
(0.04)\end{array}$ & $\begin{array}{l}1.02 \\
(0.04)\end{array}$ & $\begin{array}{l}1.85^{* * *} \\
(0.11) \\
\end{array}$ & $\begin{array}{l}1.88^{* * * *} \\
(0.09)\end{array}$ \\
\hline Metro Residence & $\begin{array}{l}0.85 \\
(0.10)\end{array}$ & $\begin{array}{l}0.97 \\
(0.13)\end{array}$ & $\begin{array}{l}0.57 * * * \\
(0.07) \\
\end{array}$ & $\begin{array}{l}0.66^{* *} \\
(0.08)\end{array}$ \\
\hline Full-Time or Part-Time Student & $\begin{array}{l}0.89 \\
(0.13)\end{array}$ & $\begin{array}{l}0.94 \\
(0.13)\end{array}$ & $\begin{array}{l}1.33^{*} \\
(0.16)\end{array}$ & $\begin{array}{l}1.21 \\
(0.14)\end{array}$ \\
\hline Resides with Related Family & $\begin{array}{l}0.51^{* * *} \\
(0.08)\end{array}$ & $\begin{array}{l}0.54 * * * \\
(0.08)\end{array}$ & \begin{tabular}{|l|}
$0.48^{* * * *}$ \\
$(0.05)$ \\
\end{tabular} & $\begin{array}{l}0.49 * * * \\
(0.06)\end{array}$ \\
\hline Resides with Unrelated Family & $\begin{array}{l}0.72 * \\
(0.11)\end{array}$ & $\begin{array}{l}0.74^{*} \\
(0.11)\end{array}$ & $\begin{array}{ll}0.98 \\
(0.13) \\
\end{array}$ & $\begin{array}{l}0.99 \\
(0.12)\end{array}$ \\
\hline
\end{tabular}


INCOME PACKAGING AND ECONOMIC DISCONNECTION

\begin{tabular}{|c|c|c|c|c|}
\hline County Unemployment Rate & & $\begin{array}{l}1.02 \\
(0.02)\end{array}$ & & $\begin{array}{l}1.12^{* * *} \\
(0.03)\end{array}$ \\
\hline $\begin{array}{l}\text { State Average TANF Benefit } \\
\text { Amount }\end{array}$ & & $\begin{array}{l}1.00 \\
(0.00)\end{array}$ & & $\begin{array}{l}1.00 \\
(0.00)\end{array}$ \\
\hline State Flexibility Index (0-12) & & $\begin{array}{l}1.03 \\
(0.03)\end{array}$ & & $\begin{array}{l}0.98 \\
(0.02)\end{array}$ \\
\hline State Cash Diversion Program Exists & & $\begin{array}{l}0.91 \\
(0.11)\end{array}$ & & $\begin{array}{l}1.04 \\
(0.11)\end{array}$ \\
\hline $\begin{array}{l}2001 \text { SIPP panel (comparison group } \\
=1996 \text { ) }\end{array}$ & $\begin{array}{l}1.09 \\
(0.14)\end{array}$ & $\begin{array}{l}1.12 \\
(0.15)\end{array}$ & $\begin{array}{l}1.05 \\
(0.11)\end{array}$ & $\begin{array}{l}0.93 \\
(0.10)\end{array}$ \\
\hline $\begin{array}{l}\text { 2004 SIPP panel (comparison group } \\
=1996 \text { ) }\end{array}$ & $\begin{array}{l}1.17 \\
(0.14)\end{array}$ & $\begin{array}{l}1.40^{* *} \\
(0.18)\end{array}$ & $\begin{array}{l}1.80^{* * * *} \\
(0.19)\end{array}$ & $\begin{array}{l}1.77 * * * \\
(0.19)\end{array}$ \\
\hline Intercept & $\begin{array}{l}0.11 * * * \\
(0.04)\end{array}$ & & $\begin{array}{l}1.23 \\
(0.35)\end{array}$ & \\
\hline \multicolumn{5}{|l|}{ Random Effects } \\
\hline Intercept for State Effects & & $\begin{array}{l}0.18^{*} \\
(0.10)\end{array}$ & & $\begin{array}{l}0.21 * * \\
(0.08)\end{array}$ \\
\hline Intercept for County Effect & & $\begin{array}{l}0.67 * * \\
(0.08)\end{array}$ & & $\begin{array}{l}0.42 * * \\
(0.09)\end{array}$ \\
\hline $\mathrm{n}$ & 5,754 & 5,754 & 5,754 & 5,754 \\
\hline Pseudo $\mathrm{R}^{2}$ & 0.044 & & 0.125 & \\
\hline Wald $\mathrm{Chi}^{2}$ & $134.78 * * *$ & $143.90 * * *$ & $398.06 * * *$ & $458.49 * * *$ \\
\hline
\end{tabular}

Notes: Models 1 and 3 are logisitic regression models with individual level independent variables. Models 2 and 4 are mixed effect, multilevel models with county and state level independent variables added. The dependent variable for Models 1 and 2 is whether or not a sample member reported private help from family, friends, or a community group. The dependent variable for Models 3 and 4 is whether or not a women reported public non-cash assistance. Odds ratios with robust standard errors in parentheses are reported.

$* \mathrm{p}<0.05, * * \mathrm{p}<0.01, * * * \mathrm{p}<0.001$ 
INCOME PACKAGING AND ECONOMIC DISCONNECTION

Table 3. Logistic and Multilevel Logistic Regression Models Explaining Economic

Disconnection $(n=5,754)$

\begin{tabular}{|c|c|c|c|c|c|c|}
\hline & \multicolumn{3}{|c|}{ Economic Disconnection } & \multicolumn{3}{|c|}{ Long-Term Economic Disconnection } \\
\hline & Model 1 & Model 2 & Model 3 & Model 1 & Model 2 & Model 3 \\
\hline \multicolumn{7}{|l|}{ Fixed Effects } \\
\hline Any Public Help & $\begin{array}{l}0.84 \\
(0.08)\end{array}$ & $\begin{array}{l}0.83 \\
(0.09)\end{array}$ & $\begin{array}{l}0.85 \\
(0.08)\end{array}$ & $\begin{array}{l}1.27 \\
(0.17)\end{array}$ & $\begin{array}{l}1.18 \\
(0.16)\end{array}$ & $\begin{array}{l}1.15 \\
(0.15)\end{array}$ \\
\hline Any Private Help & $\begin{array}{l}1.67 * * * \\
(0.16)\end{array}$ & $\begin{array}{l}1.45^{* *} \\
(0.16)\end{array}$ & $\begin{array}{l}1.51 * * * \\
(0.16)\end{array}$ & $\begin{array}{l}2.00 * * * \\
(0.24)\end{array}$ & $\begin{array}{l}1.78^{* * * *} \\
(0.22)\end{array}$ & $\begin{array}{l}1.77 * * * \\
(0.20)\end{array}$ \\
\hline \multicolumn{7}{|l|}{ Race (comparison $=$ White) } \\
\hline Black & & $\begin{array}{l}0.79 * \\
(0.07)\end{array}$ & $\begin{array}{l}0.77 * * \\
(0.07)\end{array}$ & & $\begin{array}{l}0.83 \\
(0.09)\end{array}$ & $\begin{array}{l}0.78^{*} \\
(0.09)\end{array}$ \\
\hline Latina & & $\begin{array}{l}0.65 * * * \\
(0.07)\end{array}$ & $\begin{array}{l}0.67 * * * \\
(0.08) \\
\end{array}$ & & $\begin{array}{l}0.70^{* *} \\
(0.09)\end{array}$ & $\begin{array}{l}0.69^{* *} \\
(0.10)\end{array}$ \\
\hline Other & & $\begin{array}{l}0.86 \\
(0.14)\end{array}$ & $\begin{array}{l}0.98 \\
(0.15) \\
\end{array}$ & & $\begin{array}{l}0.98 \\
(0.18)\end{array}$ & $\begin{array}{l}1.07 \\
(0.19)\end{array}$ \\
\hline Age & & $\begin{array}{l}0.99 * * \\
(0.01)\end{array}$ & $\begin{array}{l}0.99^{* *} \\
(0.00)\end{array}$ & & $\begin{array}{l}1.00 \\
(0.01)\end{array}$ & $\begin{array}{l}1.00 \\
(0.01)\end{array}$ \\
\hline Never Married & & $\begin{array}{l}0.80^{*} \\
(0.07)\end{array}$ & $\begin{array}{l}0.85 \\
(0.07)\end{array}$ & & $\begin{array}{l}0.89 \\
(0.10)\end{array}$ & $\begin{array}{l}0.97 \\
(0.10)\end{array}$ \\
\hline \multicolumn{7}{|l|}{ Education } \\
\hline Less Than High School & & $\begin{array}{l}1.29^{*} \\
(0.14)\end{array}$ & $\begin{array}{l}1.31 * * \\
(0.13)\end{array}$ & & $\begin{array}{l}1.18 \\
(0.14)\end{array}$ & $\begin{array}{l}1.22 \\
(0.14)\end{array}$ \\
\hline Some College & & $\begin{array}{l}1.03 \\
(0.09)\end{array}$ & $\begin{array}{l}1.04 \\
(0.08)\end{array}$ & & $\begin{array}{l}0.88 \\
(0.09)\end{array}$ & $\begin{array}{l}0.89 \\
(0.09)\end{array}$ \\
\hline Work-limiting Disability & & $\begin{array}{l}1.51^{* * * *} \\
(0.16)\end{array}$ & $\begin{array}{l}1.57 * * * \\
(0.15)\end{array}$ & & $\begin{array}{l}1.53 * * * \\
(0.18)\end{array}$ & $\begin{array}{l}1.64 * * * \\
(0.18)\end{array}$ \\
\hline Number of Children & & $\begin{array}{l}0.92^{*} \\
(0.03)\end{array}$ & $\begin{array}{l}0.92^{*} \\
(0.03)\end{array}$ & & $\begin{array}{l}1.02 \\
(0.04)\end{array}$ & $\begin{array}{l}1.03 \\
(0.04)\end{array}$ \\
\hline Metro Residence & & $\begin{array}{l}1.01 \\
(0.10)\end{array}$ & $\begin{array}{l}0.99 \\
(0.10)\end{array}$ & & $\begin{array}{l}1.00 \\
(0.11)\end{array}$ & $\begin{array}{l}0.98 \\
(0.11)\end{array}$ \\
\hline $\begin{array}{l}\text { Full Time or Part-Time } \\
\text { Student }\end{array}$ & & $\begin{array}{l}1.22 \\
(0.14)\end{array}$ & $\begin{array}{l}1.24^{*} \\
(0.13)\end{array}$ & & $\begin{array}{l}1.01 \\
(0.14)\end{array}$ & $\begin{array}{l}1.00 \\
(0.13)\end{array}$ \\
\hline $\begin{array}{l}\text { Resides with Related } \\
\text { Family }\end{array}$ & & $\begin{array}{l}0.27 * * * \\
(0.04)\end{array}$ & $\begin{array}{l}0.27 * * * \\
(0.03)\end{array}$ & & $\begin{array}{l}0.28 * * * \\
(0.05)\end{array}$ & $\begin{array}{l}0.26^{* * * *} \\
(0.04)\end{array}$ \\
\hline $\begin{array}{l}\text { Resides with Unrelated } \\
\text { Family }\end{array}$ & & $\begin{array}{l}2.25^{* * *} \\
(0.23)\end{array}$ & $2.20 * * *$ & & $\begin{array}{l}2.80^{* * *} \\
(0.32)\end{array}$ & $\begin{array}{l}1.56^{* * *} \\
(0.27)\end{array}$ \\
\hline $\begin{array}{l}\text { 2001 SIPP panel } \\
(\text { comparison }=1996)\end{array}$ & $\begin{array}{l}1.46^{* * *} \\
(0.13)\end{array}$ & $\begin{array}{l}1.66^{* * *} \\
(0.16)\end{array}$ & $\begin{array}{l}1.49 * * * \\
(0.15)\end{array}$ & $\begin{array}{l}1.79^{* * *} \\
(0.22)\end{array}$ & $\begin{array}{l}1.83^{* * *} \\
(0.24)\end{array}$ & $\begin{array}{l}1.66^{* * *} \\
(0.22)\end{array}$ \\
\hline $\begin{array}{l}\text { 2004 SIPP panel } \\
(\text { comparison }=1996)\end{array}$ & $\begin{array}{l}1.55^{* * * *} \\
(0.13)\end{array}$ & $\begin{array}{l}1.73 * * * \\
(0.16)\end{array}$ & $\begin{array}{l}1.54 * * * \\
(0.15)\end{array}$ & $\begin{array}{l}2.48^{* * * *} \\
(0.28)\end{array}$ & $\begin{array}{l}2.57 * * * \\
(0.31)\end{array}$ & $\begin{array}{l}2.39 * * * \\
(0.29)\end{array}$ \\
\hline $\begin{array}{l}\text { County Unemployment } \\
\text { Rate }\end{array}$ & & & $\begin{array}{l}0.99 \\
(0.02)\end{array}$ & & & $\begin{array}{l}0.99 \\
(0.02)\end{array}$ \\
\hline $\begin{array}{l}\text { State Average TANF } \\
\text { Benefit Amount }\end{array}$ & & & $\begin{array}{l}1.00 \\
(0.00)\end{array}$ & & & $\begin{array}{l}0.99 * \\
(0.00)\end{array}$ \\
\hline $\begin{array}{l}\text { State Flexibility Index (0- } \\
12)\end{array}$ & & & $\begin{array}{l}1.01 \\
(0.02)\end{array}$ & & & $\begin{array}{l}0.99 \\
(0.02)\end{array}$ \\
\hline
\end{tabular}


INCOME PACKAGING AND ECONOMIC DISCONNECTION

\begin{tabular}{|c|c|c|c|c|c|c|}
\hline $\begin{array}{l}\text { State Cash Diversion } \\
\text { Program Exists }\end{array}$ & & & $\begin{array}{l}1.10 \\
(0.10)\end{array}$ & & & \begin{tabular}{|l|}
1.08 \\
$(0.12)$ \\
\end{tabular} \\
\hline Intercept & $\begin{array}{l}0.196 * * * \\
(0.019)\end{array}$ & $\begin{array}{l}0.447 * * \\
(0.107) \\
\end{array}$ & & $\begin{array}{l}0.058^{* * *} \\
(0.009)\end{array}$ & $\begin{array}{l}0.073 * * * \\
(0.021)\end{array}$ & \\
\hline \multicolumn{7}{|l|}{ Random Effects } \\
\hline Intercept for State Effects & & & $\begin{array}{l}0.140 * * \\
(0.068)\end{array}$ & & & $\begin{array}{l}0.196^{* *} \\
(0.074)\end{array}$ \\
\hline Intercept for County Effect & & & $\begin{array}{l}0.268 * * \\
(0.082)\end{array}$ & & & \begin{tabular}{|l}
$0.291 * *$ \\
$(0138)$ \\
\end{tabular} \\
\hline Pseudo $\mathrm{R}^{2}$ & 0.011 & 0.070 & & 0.028 & 0.086 & \\
\hline Wald Chi $^{2}$ & $60.84 * * *$ & $304.92 * * *$ & $320.55 * * *$ & $113.97 * * *$ & $298.00 * * *$ & $308.43 * * *$ \\
\hline
\end{tabular}

Notes: Models 1, 2, 4 and 5 are logistic regression models with individual level independent variables. Models 3 and 6 are mixed effect, multilevel models with county and state level independent variables included. The dependent variable in Models 1, 2, and 3 is whether or not a woman is economically disconnected, defined as reporting no TANF, SSI or earned income during any wave of the panel. The dependent variable for Models 4, 5, and 6 is whether or not a women is economically disconnected for more than half of the waves of the panel study. Odds ratios with robust standard errors in parentheses are reported.

$* \mathrm{p}<0.05, * * \mathrm{p}<0.01, * * * \mathrm{p}<0.001$ 